\title{
HYPOTHESIS
}

\section{A new, cheap method to reduce bird mortality from window collisions}

\author{
Julián Monge-Nájera \& Zaidett Barrientos Llosa \\ Laboratorio de Ecología Urbana, Universidad Estatal a Distancia (UNED), 2050 San José, Costa Rica, julianmonge@gmail.com
}

Received 20-X-2017 • Corrected 14-XI-2017 • Accepted 12-XII-2017

\begin{abstract}
Many methods to prevent bird deaths at windows are ineffective, and some useful methods are expensive or displeasing. Here we offer, for free download, an image that reduced bird accidents on large windows near a tropical cloud forest area, and propose hypotheses for its experimental evaluation.
\end{abstract}

Key words: reduction of bird mortality, predator-avoidance behavior, reaction of birds to cats.

Bird injury and death from collisions with window glass is a significant problem around the world (Menacho-Odio, 2015; Hager et al., 2017). Unfortunately, even though public participation and awareness are growing (Oviedo \& Menacho-Odio, 2015; Kummer, Bayne \& Machtans, 2016), methodological problems limit our understanding of the problem and its remediation (Loss, Loss, Will \& Marra, 2016).

Some methods to prevent bird deaths at windows are ineffective, and some effective methods are expensive or displeasing (for a methods review, see Cowell, Dietrich, Sullivan \& Messmer, 2017). Here we present several hypotheses based on observations with a printed photograph that helped reduce bird mortality on large windows near a tropical cloud forest area. We include the photograph (free download)

The building where the test was done is surrounded by cattle grassland and is $70 \mathrm{~m}$ from tropical riparian cloud forest in Coronado, Costa Rica $\left(10^{\circ} 00^{\prime} 42^{\prime \prime} \mathrm{N}\right.$, $\left.83^{\circ} 57^{\prime} 58^{\prime \prime} \mathrm{W}\right)$. No detailed records were kept because it was impossible to keep observers in the house all the time, but our experience is that bird collisions were rare in the first five years. More than half the victims died on impact, others died after a few minutes, and a few recovered and flew away.
RESUMEN: Un método barato para reducir la mortalidad de aves por choque con ventanas. Muchos métodos para evitar la muerte de aves en ventanas son ineficientes, y algunos métodos eficaces resultan caros o desagradables. Aquí ofrecemos, para descarga gratuita, una imagen que redujo las muertes de aves en la cercanía de un bosque tropical nuboso. Además, proponemos hipótesis para su evaluación experimental.

Palabras clave: reducción de mortalidad, evasión de depredadores, reacción de aves ante gatos.
After the fifth year, secondary vegetation grew closer to the building and birds started to die every week and then every day, leading us to look for a solution. After noticing that no birds hit when our cats were closed to the windows, we decided to test a photograph of one of them, a novel idea that to our knowledge has not been published before.

On May $17^{\text {th }}, 2017$, we pasted to the base of one window a $30 \mathrm{~cm}$ tall color photograph of our cat Negrito (Fig. 1) and no more deaths took place in that window, so on August $5^{\text {th }}, 2017$ we added the photograph to the remaining seven windows. Since then (almost a year at the date of this publication) we have only witnessed one bird death in windows with the cat image (and five collisions in which the birds survived).

The idea of using a predator image to save birds is not new: hawk silhouettes have been used for years, but they were not successful; basically, only threads, nets or materials that cover a significant part of the window had worked until now (see Klem, 1990, Menacho-Odio, 2018). We think that previous predator images failed because they were not realistic enough to scare birds, leaving only the option of covering much of the glass, which is often not a desirable practice from the point of view of the human occupants of buildings, who build large 


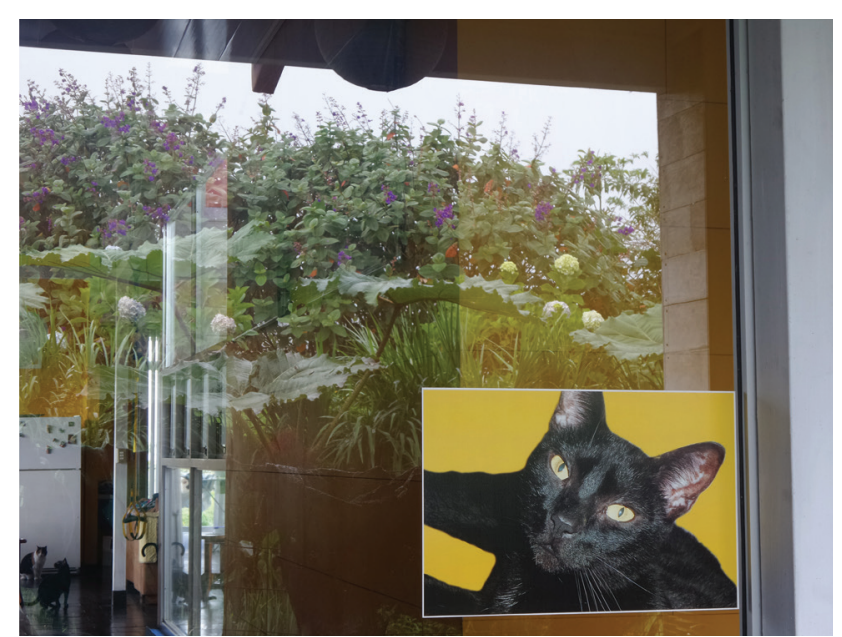

Fig. 1. Cat photograph that prevented deaths from bird collisions when placed on windows near a tropical cloud forest.

windows to get an unobstructed view of the scenery. In our experience, this image of a cat, visible from a long distance thanks to its contrasting colors, shape and size, prevented further deaths. We hope others will use it and report on its efficacy, hopefully pasting it in in the outside of some windows (to prevent reflections) and leaving other windows as experimental controls, to see the before-and-after difference in the number of birds dying. A similar image, but with random areas of black and yellow, can be used as part of the control to see if it is really the cat image that produces the avoidance effect in birds. If our results are confirmed, tests should be made to measure the area that each image provides, as well as the best position of the photograph in the window.

Our hypotheses are that the image of a predator prevents more accidents that the image of an herbivore; that color images work better than gray images or silhouettes; and that images in which you see the eyes clearly or show the open mouth of a predator avoid more collisions. Of course, many other hypotheses can be imagined by future researchers.

\section{ACKNOWLEDGMENTS}

We thank an anonymous reviewer for suggestions to improve the manuscript.

\section{REFERENCES}

Cowell, S., Dietrich, C., Sullivan, K., \& Messmer, T. (2017). Reducing the Risk of Birds Colliding into Windows: A Practical Guide for Homes and Businesses. Utah State University Extension Paper, 1661. Retrieved from http:// digitalcommons.usu.edu/extension_curall/1661

Hager, S. B., Cosentino, B. J., Aguilar-Gómez, M. A., Anderson, M. L., Bakermans, M., Boves, T. J., ... \& Calderón-Parra, R. (2017). Continent-wide analysis of how urbanization affects bird-window collision mortality in North America. Biological Conservation, 212, 209-215. doi: 10.1016/j.biocon.2017.06.014

Klem, D., Jr. (1990). Collisions between birds and windows: Mortality and prevention. Journal of Field Ornithology, 61(1), 120-128.

Kummer, J. A., Bayne, E. M., \& Machtans, C. S. (2016). Use of citizen science to identify factors affecting bird-window collision risk at houses. The Condor, 118(3), 624-639. doi: 10.1650/CONDOR-16-26.1

Loss, S., Loss, S., Will, T., \& Marra, P. (2016). Best practices for data collection in studies of bird-window collisions. Retrieved from http://abcbirds.org/wp-content/uploads/2015/11/ Loss-et-al-Best-Practices-for-Window-Data-2014.pdf

Menacho-Odio, R. M. (2015). Colisión de aves contra ventanas en Costa Rica: conociendo el problema a partir de datos de museos, ciencia ciudadana y el aporte de biólogos. Zeledonia, 19, 10-17.

Menacho-Odio, R. M. (2018). Local perceptions, attitudes, beliefs, and practices toward bird-window collisions in Monteverde, Costa Rica. UNED Research Journal, 10(1), 33-40.

Oviedo, S., \& Menacho-Odio, R. M. (2015). Actitud en la preferencia de métodos para evitar el choque de aves contra puertas y ventanas de vidrio en Costa Rica. Zeledonia, $19,22-31$.

\section{EDITED BY CAROLINA SEAS}

See Digital Appendix at: / Ver Apéndice digital en: http://investiga.uned.ac.cr/revistas/index.php/cuadernos 